\title{
A Family of the Nação from the Atlantic to the Mediterranean and Beyond (1497-1640)
}

\author{
James Nelson Novoa
}

At some point in late 1595, a ship arrived in Lisbon carrying several prisoners on their way from Brazil to face trial through the tribunal of the Inquisition of Lisbon, which oversaw Portugal's Atlantic possessions in the matters of faith. The accused were individuals who came under scrutiny in the first inquisitorial visitation in the northeast of Brazil under Frei Heitor Furtado de Mendoça who had arrived there in June 1591. As there never was an independent tribunal of the Portuguese Inquisition in Brazil, it was dependent on the tribunal of Lisbon, and this visitation was the way in which the tribunal could impose orthodoxy in the overseas territory. ${ }^{1}$ Among the prisoners who arrived was a native of Porto, Bento Teixeira, who would go on to be hailed as Brazil's first

1 On the visitation, see José Antônio Gonsalves de Mello, "Um tribunal da inquisição em Olinda, Pernambuco (1594-1595)," in Revista da Universidade de Coimbra 36 (1991): 369-74; Luiz Mott, Primeira visitação do santo ofíicio a Bahia (1591) (EDUFBA, 2010), 1-26, http:// books.scielo.org/id/yn/pdf/mott-9788523208905-03. Emanuel Luiz Souza e Silva, "Juntos à Forca': A Família Lopes e a Visitação do Santo Oficio à Bahia (1591-1593)," Master's thesis, Universidade Estadual de Feira de Santana, 2010; Angelo Adriano Faria de Assis, "O licenciado Heitor Furtado de Mendonça, inquisidor da primeira visitação do Tribunal do Santo Ofício ao Brasil," in Anais do XXIII Simpósio Nacional de História (Londrina: ANPUH, 2005) cd-rom. The texts of the confessions and denunciations gathered during the visitation are published in Primeira visitação do santo ofício as partes do Brasil pelo licenciado Heitor Furtado de Mendoça, Confissões da Bahia 1591-1592, ed. João Capistrano de Abreu (São Paulo: Homenagem de Paulo Prado, 1922); Primeira visitação do santo ofício as partes do Brasil pelo licenciado Heitor Furtado de Mendoça, Confissões da Bahia 1591-1593, ed. João Capistrano de Abreu (São Paulo: Homenagem de Paulo Prado 1925); Primeira visitação do santo ofício as partes do Brasil pelo licenciado Heitor Furtado de Mendoça, Confissões da Bahia 1593-1595, ed. João Capistrano de Abreu (São Paulo: Homenagem de Paulo Prado, 1929). Recently the confessions in Bahia from 1591-1593 were published in Santo Oficio da Inquisição de Lisboa. Confissões da Bahia, ed. Ronaldo Vainfas (São Paulo: Companhia das Letras, 1997). On New Christians in Brazil during the period see Bruno Feitler, Inquisition, juifs et nouveaux-chrétiens au Brésil. Le Nordeste XVII et XVIII'̀me siècles (Louvain: Presses Universitaires de Louvain, 2003); José Antônio Gonsalvez de Melo, Gente da nação (Recife: Editora Massangana, 1996); the following books by José Goncalves Salvador, Os cristãos novos. Povoamento e conquista do solo brasileiro (1530-1680) (São Paulo: Livraria Pioneira Editora, Editora da Universidade de São Paulo, 1976); Os cristãos novos e o comércio no Atlântico meridional (São Paulo: Livraria

(C) JAMES NELSON NOVOA, 2019 | DOI:10.1163/9789004392489_003

This is an open access chapter distributed under the terms of the prevailing CC-BY-NC License at the time of publication. 
published poet. Teixeira was but one component of this New Christian family whose run-ins with inquisitiorial justice were to be ongoing. The family's links were to extend from continental Portugal to Brazil and Italy and eventually to the Sephardic community of Amsterdam, a show of the kind of interconnectedness of kin and sociability in the New Christian diaspora that extended from the Mediterranean to the Atlantic.

The case closely mirrors that of other individuals who were part of extended family connections that brought together both the worlds of the Mediterranean and the Atlantic. Increasingly, scholarship that is indebted to economic and social history is bridging this gulf, concentrating on bringing these two worlds together, showing their interconnectedness. The New Christian diaspora and its manifold, often sinewy, networks within this Mediterranean-Atlantic divide has increasingly been the subject of research for scholars in a variety of fields. ${ }^{2}$ The concrete case of this family at the end of the sixteenth century and beginning of the seventeenth serves as an example of the connections of kin across this great divide. The case of the family also evinces the complexity of attributing a hegemonic religious identity to the New Christian diaspora. Over the space of two centuries it included members who were accused of being heretics by both Catholic and Jewish authorities and others who apparently held steadfast to religious orthodoxy. The example demonstrates the many contours that New Christian identity could take, from the full embrace of the Christian faith forcibly assumed by Portugal's Jews in 1497, to its lukewarm acceptance, and its rejection.

Since the study of the New Christian phenomenon began in earnest close to a hundred years ago, there has often been a tendency to conceive of them as inevitable potential Jews, individuals who, given the chance, would necessarily embrace the faith of their ancestors. This return to the faith of their forefathers in Sepharad has often been posited as something essential, as the only real option available to them. Recently, scholars such as David Graizbord, ${ }^{3}$ Lucia

Pioneira Editora, Editora da Universidade de São Paulo, 1978); Anita Novinsky, Cristão novos na Bahia (São Paulo: Editora da Universidade de São Paulo, 1972).

2 See, for example, Jonathan I. Israel, Diasporas within a Diaspora: Jews, Crypto-Jews and the World Maritime Empires, 1540-1740 (Leiden: Brill, 2002); Richard L. Kagan and Philip D. Morgan, eds., Atlantic Diasporas. Jews, Conversos and Crypto-Jews in the Age of Mercantilism, 1500-1800 (Baltimore: The Johns Hopkins University Press, 2009); Daviken Studnicki-Gizbert, A Nation upon the Ocean Sea. Portugal's Atlantic Diaspora and the Crisis of the Spanish Empire, 1492-1640 (New York: Oxford University Press, 2007); Francesca Trivellato, The Familiarity of Strangers: The Sephardic Diaspora, Livorno, and Cross-Cultural Trade in the Early Modern Period (New Haven: Yale University Press, 2009).

3 David Graizbord, “Religion and Ethnicity among 'Men of the Nation': Towards a Realistic Interpretation," Jewish Social Studies: History, Culture, Society 15, no. 1 (2008): 32-65. 
Frattarelli Fischer, ${ }^{4}$ Federica Ruspio, ${ }^{5}$ and Ignacio Pulido Serrano have called for a decidedly mitigated interpretation of religious identity, which allows for various readings and interpretations. ${ }^{6}$

The case I wish to dwell on, of a family from Porto over the span of two centuries, reveals the broad spectrum of religious options that were possible for members of the Nação in various locales. Some of them chose the route of some form of adherence to Jewish belief and practice, however nuanced or vague, even at the risk of reputation, livelihood, and physical wellbeing. Others, even when the choice of an embrace of the Jewish faith did not occasion danger, chose to hold steadfast to the faith they had been reared in. This variety within this family from Porto is a telling testimony to how the religious identity of the Nação is multilayered and complex, and evades facile definitions.

\section{1 \\ Bento Teixeira: A Study in Ambiguity}

According to the account of his life which appears in his inquisitorial trial by the tribunal of Lisbon held in the Torre do Tombo archive as trial 5206, Bento Teixeira was born around 1560 in Porto, the son of one Bento Mendez, a New Christian merchant, and Leonor Rodriguez. ${ }^{7}$ At the age of three, after leaving Lisbon, where his family settled for a few years, he left Portugal, along with a brother, Fernando Rodríguez da Paz, whose name could indicate his possible links to the well-known New Christian Paz family based in Porto, for Brazil. He first settled in the captaincy of Espiritu Santo, then Tapera, and Rio de Janeiro, being privy to a Jesuit formation all the while, which trained him in Latinidade, something which was to be at the heart of his activities throughout his troubled existence. ${ }^{8}$ He received schooling in the Classics and the Bible along with the rudiments of Italian and Spanish, which put him into contact with the literary trends then predominant in the Italian and Iberian peninsulas, something

4 Lucia Frattarelli Fischer, "Ebrei a Pisa fra Cinquecento e Settecento," Gli ebrei di Pisa (secoli IX-XX). Atti del Convegno internazionale. Pisa, 3-4 ottobre 1994 (Pisa: Pacini editore, 1998), 89-115; "Cristiani nuovi e nuovi ebrei in Toscana fra Cinque e Seicento: Legittimazioni e percorsi individuali," in L'identità dissimulata. Giudaizzanti iberici nell'europa dell'età moderna, ed. Pier Cesare Ioly Zorattini (Florence: Olschki, 2000), 217-31; Vivere fuori dal Ghetto. Ebrei a Pisa e Livorno (secoli XVI-XVIII) (Turin: Silvio Zamorani Editore, 2008), 15-68.

5 Francesca Ruspio, La nazione portoghese. Ebrei ponentini e nuovi cristiani a Venezia (Turin: Silvio Zamorani editore, 2007); "Una comunità di marrani a Venezia," Zakhor 5 (2001): 53-85.

6 Juan Ignacio Pulido Serrano, "Plural Identities: The Portuguese New Christians," Jewish History 25 (2011): 129-51.

7 Processo da Inquisição de Lisboa, 5206 .

8 Ibid., fols. 10or-v. 
borne out in the literary work he is associated with and which would be published posthumously, the Prosopopeia, an epic poem in ninety-four strophes.

Settling for a time in Ilheus, near Bahia, he married a woman of Old Christian stock, one Felipa Raposa. From there he moved to the city of Olinda, which boasted an important New Christian community at the time. He quickly became known as a teacher of Latin grammar and set up his own school, which provided children with Classical learning. ${ }^{9}$ He subsequently opened a school for children in the town of Igarassu. It was there that his wife's adulterous behavior began with the connivance of the local population until Teixeira killed her. ${ }^{10} \mathrm{He}$ took refuge in a Benedictine monastery after being offered hospitality from a sympathetic Benedictine brother. ${ }^{11}$ It was upon leaving the confines of the monastery though that he was apprehended for an entirely different reason. Frei Hurtado de Mendoça, who had undertaken his visitation of the northeast of Brazil as the representative of the tribunal of the Inquisition of Lisbon ordered his arrest on 19 August 1595 after having gathered information on him. ${ }^{12}$

He came under scrutiny on account of the testimony of several people who knew him to be an inciter to Jewish belief and practice, a blasphemer, and heretic. There were multiple accounts of his disbelief from both Old and New Christians. He refused to teach on Saturdays according to one Domingos Fernandes, an old Christian from Rio da Janeiro who had been a pupil of Teixeira's in his Latin school. ${ }^{13}$ João da Rosa, a New Christian, claimed that he had heard him repudiate the doctrine of the Trinity. ${ }^{14}$ Another New Christian, Antonio da Rosa, brought forward a similar allegation. ${ }^{15}$ Braz de Matta, an Old Christian, claimed he had said that his home was just as sacred as a church. ${ }^{16}$ Gaspar Rodrigues claimed that Teixeira possessed a copy of Jorge de Montemayor's (150-1561) pastoral poem La Diana that was listed among the Index of Forbidden Books. When confronted by Rodrigues, Teixeira claimed that he was aware and that he would burn it. ${ }^{17}$ One Jorge Thomas Pinto, a New Christian from Porto who lived in Bahia, depicted him as a blasphemer who put into question the validity of the sacraments even if he was not sure that he

Processo da Inquisição de Lisboa, 5206, fol. 101r. On New Christians in Olinda at the time, see José Luiz Mota Menezes, A recriação do paraíso. Judeus e cristão-novoa em Olinda e no Recife nos séculos XVI e XVII (Recife: Companhia Editora de Pernambuco, 2016).

10 Processo da Inquisição de Lisboa, 5206, fols. 101v-103v.

11 Ibid., fol. 103v.

12 Ibid., fol. 3 r.

13 Primeira Visitação, 2: 40.

14 Ibid., 2: 42-43.

15 Ibid., 2: 291-93.

16 Ibid., 2: 129-30.

17 Ibid., 2: 170. 
observed Judaic ceremonies and practices. ${ }^{18}$ While in the refuge of the monastery, he had apparently spoken frequently with one Frei Damião da Fonseca with whom he engaged in erudite exchanges. The friar had diligently taken note of some of Teixera's positions which were suspect. The New Christian teacher apparently claimed that Adam would have died independently of original sin, and he cast doubt on the Trinity. To this was added the poet and grammarian's origins which the friar caught on to. ${ }^{19}$

These warranted his formal accusation and dispatch to Portugal, leaving from Recife in October 1595. The saga would drag on for years, only ending in 1599 with Teixeira's confessing to having adopted some aspects of Jewish belief and which he reneged. He died shortly after, his Prosopopeia appearing posthumously along with Naufragio que passou Jorge de Albuquerque Coelho, Capitão e Governador de Pernambuco, a work about a shipwreck, which was dedicated to Jorge d'Albuquerque Coelho (1539-c. 1596), the governor of the captaincy of Pernambuco at the time, whose ship was attacked by French pirates and who was left at sea only to miraculously survive (Figs. 2.1 and 2.2). ${ }^{20}$ In his epic poem, also dedicated to Jorge d'Albuquerque Coelho, who had gone on to Lisbon where he died during Teixeira's imprisonment, he presents the adventures of the Albuquerque family, as recounted by Proteus to several Greek gods who meet in the port of Recife. The work, along with the Naufragio, was seen by critics as a servile act of ingratiation by an author hoping to curry favor with the Albuquerque family, perhaps even to be able to return to Brazil. Curiously, the censor's note allows for the publication of the work, apparently oblivious to the stricture that persons condemned by the Inquisition should not be allowed to publish books. ${ }^{21}$

18 Ibid., 2: 289-90.

19 Ibid., 2: 453-54. Teixeira's account of the discussions between the two come out in his trial. Processo da Inquisição de Lisboa, 5206, fols. 103v-104r.

20 Naufragio, que passou Jorge D'Albuquerque Coelho, capitão e governador de Pernambuco (Lisbon: por António Alvarez, vendemse em casa de António Ribeyro livreyro em a Rua Nova, 1601). Subsequent editions are Bento Teixeira, Prosopopea, ed. Benjamin Franklin Ramiz Galvão (Rio de Janeiro: Tipografia do Imperial Instituto Artístico, 1873); Prosopopea, ed. Afrânio Peixoto (Rio de Janeiro: Academia Brasileira, 1923); Naufrágio que passou Jorge de Albuquerque Coelho vindo do Brasil para este reino do ano de 1565, ed. Augusto César Pires de Lima (Porto: Livraria Simões Lopes de Domingos Barreira, 1938). On Albuquerque, see Charles Ralph Boxer, "Jorge d'Albuquerque Coelho: A Luso-Brazilian Hero of the Sea, 1539-1602," Luso-Brazilian Review 6, no. 1 (1969): 3-17.

21 "Vi e examinei este discurso e Naufragio, que passaou Jorge d'Albuquerque. Hé tratado pio e catholic e que não tem cousa que offenda as orelhas cristãs. Vay junto a elle huma Prosopopéia feyta por Bento Teyxeyra, dirigida ao mesmo Jorge D’Albuquerque. Não tem cousa por onde se não possa imprimir. Frey Manoel Coelho." On censorship in Portugal at 

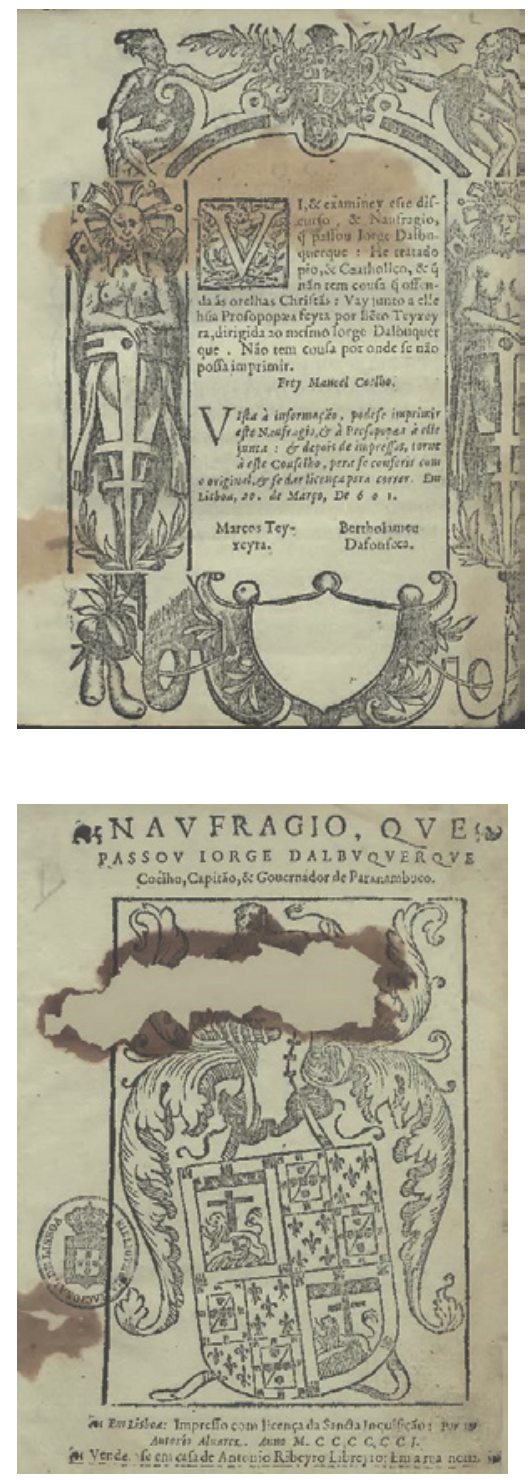

FIGURE 2.1

Permission for printing of Naufragio que passou Jorge de Albuquerque Coelho, Capitão e Governador de Pernambuco and Prosopopeia COURTESY OF THE BIBLIOTECA NACIONAL DE PORTUGAL. SHELFMARK RES. 392 P
FIGURE 2.2

Title page of Naufragio, Lisbon, Antonio Alvarez, 1601 COURTESY OF THE BIBLIOTECA NACIONAL DE PORTUGAL. SHELFMARK RES. $392 \mathrm{P}$

Bento Teixeira has received little critical attention. He appears generally as an almost anecdotal figure in Brazilian letters, a decidedly minor character in the literary landscape of the Portuguese language. It was Gilberto Freyre who first tentatively identified Teixeira the writer with the man denounced in Mendoça's

the time, see Jesus Maria de Bujanda, ed., Index de l'Inquisition portugaise 1547, 1551, 1564, 1581 (Sherbrooke: Centre d'Études de la Renaissance, 1995). 
visitation when the relevant texts were first published in $1925 .{ }^{22}$ Since then, he has been the subject of several articles, doctoral theses, and even books. ${ }^{23}$ The entire trial, made up of 401 folios, has yet to be fully and systematically studied, and it provides a fascinating glimpse into early colonial Brazilian society and the place of New Christians in it. The wealth of information it provides lays bare the complexity of social relations in that society with its divisions, rivalries, disputes, suspicions, and accusations.

In it, he provides a portrait of himself as a divided soul, similar in kind to other New Christians. His Judaizing was, he claimed, inculcated in him by his mother, while his father had done all he could to rear him in the Christian faith and dissuade him from his wife's coaxing. While his Jesuit teachers all recalled him as a studious and dutiful Christian who complied with the requirements of religious practice, other people provided an alternative take on Teixeira's character. He apparently lived a parallel life, true to the Jewish heritage his mother had passed onto him. At the trial, he provided an eloquent refutation of what he called "his errors," laced with erudite allusions to the Church Fathers and Saint Thomas Aquinas, warranting his being sentenced, on 31 January 1599, to Catholic indoctrination in the so-called "cárceres da penitencia," in the Estaus palace. ${ }^{24} \mathrm{He}$ was released shortly afterwards, with inquisitorial officials making note of his exemplary behavior, and regular attendence at church.

22 Gilberto Freyre, “Acerca da Prosopopéia," Revista de Pernambuco 1, no. 1 (1927): 2-61.

23 José Antônio Gonsalves de Melo, "Bento Teixeira, autor da Prosopopéia," in Estudos Pernambucanos. Crítica e problemas de algumas fontes de história de Pernambuco (Recife: Fundarpe, Direitoria de Assuntos Culturais, 1986), 13-52, Elvira Cunha de Azevedo Mea, “Os cristãos-novos, a Inquisição e o Brasil. Séc. XVI," Revista da Faculdade de Letras do Porto 2, no. 4 (1987): 151-77; Luiz Roberto Alves, Confissão, poesia e inquisição (São Paulo: Ática, 1983); Rogério Chociay, “Bento Teixeira e Camões: o verso no verso," Revista de Letras 31 (1991): 17-32; Gilberto Vilar de Carvalho, O primeiro brasileiro (São Paulo: Marco Zero, 1995); Lúcia Helena Costigan, Through Cracks in the Wall. Modern Inquisitions and New Christian Letrados in the Iberian Atlantic World (Leiden and Boston: Brill, 2010); Costigan, "Empreendimento e resistência do cristão-novo face à política de Filipe II: O processo inquisitorial de Bento Teixeira," Colonial Latin American Review 12, no. 1 (2003): 37-61; Costigan, "A experiência do converso letrado Bento Teixeira: Um missing link na história intelectual e literária do Brasil-colônia," Revista de Crítica Literaria Latinoamericana 2040 (1994): 77-92. Eneida Beraldi Ribeiro, "Bento Teixeira: Inquisição e sociedade colonial," WebMosaica 4, no. 1 (2012): 50-56; and Ribeiro, "Bento Teixeira e a 'Escola de Satanás.' O Poeta que teve a 'prisão por recreação, a solidão por companhia e a tristeza por prazer'," PhD diss., University of São Paulo, 20o6; Lucinéa Rinaldi, "Entre a Prosopopeia e a viagem: Poética e narrativa por letras coloniais," PhD diss., University of São Paulo, 2016.

Processo da Inquisição de Lisboa, 5206, fol. $401 v$. 
Destitute and stricken ill with fever, he presented himself anew to the prison of the Inquisition in April 1600 . He died in August of that year. ${ }^{25}$

\section{A New Christian Family from Porto}

Among the individuals mentioned in the trial was a relative and fellow native of Porto, Miguel Fernandes. In December 1597, Teixeira related some conversations held with Old and New Christians in Brazil that were the source of religious controversy. He recollected a conversation held one evening after a dinner in 1580, in Miguel Fernandes's Bahian home. A group of New Christians had gathered there and the conversation shifted to whether the Messiah had come or not. Miguel Fernandes, Gonçalo Mendes, Lionel Mendes, and Diogo Fernandes Teves, especially, sought out the opinion of Bento Teixeira regarding the matter, alluding to his erudition, which they all held in great esteem. The conclusion of all those present was that the Messiah had not yet arrived and that the Law of Moses was their only path to salvation. It also transpired that, whenever possible, they held steadfast to some form of Jewish practice, including fasting and abstinence from pork. At the end of his deposition, the Brazilian poet clearly identified Treves and Fernandes as cousins on his mother's side. ${ }^{26}$

Israël Salvator Révah's painstaking archival work has provided us with a breakdown of Miguel Fernandes's family origins, which firmly situated him, as Teixeira, in Porto. Fernandes's Judaizing tendencies did not only come to be known during Bento Teixeira's trial. The arrival of Frei Mendoça was also an occasion to make what was considered Fernandes's deviant behavior known to the inquisitorial authorities. He was accused of irreverent behavior in church and his New Christian origins were no secret. ${ }^{27}$

Révah identified Fernandes's parents as Dinis Aenes (1510?-1565?) and Florença Fernandes (died 1570?), New Christians from Porto. ${ }^{28}$ Dinis Aenes was a prominent figure among his fellow merchants thanks to a trade network

\footnotetext{
25 A note on the first folio of the trial states "He falecido Bento Teixeira, e falleçeo andando com [...] e no fim de Julho de 16oo." Ibid., fol. rr.

26 The conversation has been presented and translated into French in Israël Salvator Révah, Uriel da Costa et les marranes de Porto. Cours au Collège de France 1966-1972, ed. Carsten L. Wilke (Paris: Fundação Calouste Gulbenkian, 2004), 344-47. The relevant passages are to be found in Inquisição de Lisboa, processo 5206 , fols. 308v-310r.

27 Révah, Uriel da Costa, 349-50.

28 Ibid., 126-27.
} 
that spanned the Mediterranean and the Atlantic. ${ }^{29}$ It was also well known that Aenes was a New Christian, the son of one Alvaro Rodrigues and Violante Rodrigues, Jews who had converted to Christianity in the general conversion of $1497{ }^{30}$ Suspicions regarding Aenes's orthodoxy and that of his parents and first wife, Isabel Nunes, led to his arrest in April 1543 by the tribunal of the shortlived Inquisition of Porto, one of a few tribunals to exist in Portugal from 1541 to $1547 .{ }^{31}$ Aenes was made to publicly renounce his alleged Jewish practices on 3 September 1543, with a display of public penance at the cathedral of Porto and a monetary contribution to be made for pious works, a light sentence, which Révah interpreted as a reflection of the dubious veracity of the accusations brought forward by witnesses of suspicious intent and character. ${ }^{32}$

Miguel Fernandes was the son of Aenes's second marriage with Florença Fernandes, one of five children including Margarida Dinis, Branca Dinis, Álvaro Rodrigues, and Jácome Rodrigues, born and raised in that New Christian hub of the rua de São Miguel in Porto. ${ }^{33}$ In a deposition before the tribunal of the Roman Inquisition, a trial from 1595, to be addressed more fully below, Miguel declared that he was forty-two years of age, which places his birth in the year 1553. The declarations in the Roman trial complement the information gathered by Révah regarding Fernandes and the family. In childhood, he had his first direct experience of the workings of inquisitorial justice when, in 1565, the tribunal of the Holy Office investigated his mother, by then a widow, on allegations of Judaizing, though it was concluded that there was insubstantial evidence of Jewish practices. ${ }^{34}$

He left Portugal for Brazil at the age of seventeen in pursuit of fortune. He returned to his homeland for a short time after participating in the disastrous battle of Alcácer Quibir in 1578. He then went back to Brazil, where he fought alongside Cristovão de Barros in the conquest of Sergipe, earning him a knighthood. It was during this second sojourn in Brazil that he lived in Bahia,

29 On Porto's merchants and Porto in the sixteenth century, see Amândio Jorge Morais Barros, "Barcos e gentes do mar do Porto (séculos XIV-XVI)," Revista da Faculdade de Letras 14 (1997): 167-230.

30 Révah, Uriel da Costa, 149.

31 On the tribunal, see Elvira Cunha de Azevedo Mea, "A Inquisição do Porto," Revista de História 2 (1979): 215-27 and Giuseppe Marcocci and José Pedro Paiva, "Inquisizione di Porto," in Dizionario storico dell'Inquisizione (Pisa: Edizioni dela Normale, 2010), 3:1240-41.

32 Révah, Uriel da Costa, 155-76.

33 Ibid., 188-89.

34 Ibid., 190-94. 
where he apparently married Feliciana Teixeira, the daughter of his cousin, Rui Teixeira, who was, in turn, married to one Branca De Nis. ${ }^{35}$

To date, little is known of Rui Teixeira's presence in Brazil, his activities there, or his relations in the territory. His name, however, does surface in the denunciations compiled by Frei Mendoça during his sojourn to Brazil, though he was no longer living there at the time. In 1591, an Old Christian from Porto by the name of Paulo Moreira claimed that Rui was then living in Lisbon but that four years before he had been present in Brazil where he acted as the agent of a merchant from Lisbon, one Bento Dias Santiago. He was accused of declaring that he believed as much in his black servant as in the Gospel of Saint John. His words, overheard by other people, had been a cause of scandal. ${ }^{36} \mathrm{~A}$ similar accusation was leveled against him by an Old Christian from the Algarve, Francisco Roiz Castilho. ${ }^{37}$ Like Miguel Fernandes and his cousin Bento Teixeira, the accusations of some form of allegiance to the Jewish faith were thus made against Rui Teixeira as well during the investigations undertaken in that remote territory of the Hispanic empire.

\section{Tuscan Reinvention}

Fernandes's second stay in Brazil lasted from 1587 to 1593 , after which he returned to Portugal where he lived but briefly. From there he made his way to Pisa, where he was sought after by Granduke Ferdinando I (1587-1609), who entreated the resident apostolic collector in Portugal, Fabio Biondi (1533-1618), to secure his safe passage to the Tuscan town along with his father-in-law and their families. They apparently settled there in February 1594, a year before Bento Teixeira was apprehended. ${ }^{38}$ Ferdinando had recently been a force behind the so-called Livornine of 1591 and 1593 intended to attract international merchants to the port of Livorno and turn it into a maritime commercial hub by extending to Portuguese New Christian merchants the privilege to settle in the town free from inquisitorial prying on possible past accusations

35 James Nelson Novoa, "The Many Lives of Two Portuguese Conversos: Miguel Fernandes and Rui Teixeira in the Tribunal of the Holy Office in Rome," HispaniaJudaica 12 (2016): 134. On Fernandes and Teixeira see, in addition, Nelson Novoa, "Negotiating Identity Among the Nação in Early Modern Rome," in Early Modern Ethnic and Religious Communities in Exile, ed. Yosef Kaplan (Newcastle upon Tyne: Cambridge Scholars Publishing, 2017): $242-76$.

36 Testimony given on 7 August 1591, Primeira Visitação [...], 2: 292-93.

37 Ibid., 2: 292-93.

38 Nelson Novoa, "The Many Lives," 133-34. 
of unorthodoxy. The measures also allowed for a crucial modification: the possibility for Jews to create a new Jewish community with a synagogue and for baptized Iberians to convert to Judaism and join it. ${ }^{39}$ This measure echoed a similar one undertaken in 1589 in Venice where the authorities allowed Iberian Jews, known as ponentini, by definition converts to Judaism from Christianity, the possibility to settle in the city. ${ }^{40}$

It was the Brazilian historian Sergio Buarque de Holanda who first drew the attention of historians to the fact that Ferdinando was especially keen on securing ties to Brazil, making plans for an elaborate scheme of Tuscan colonization of the Amazon that never materialized. The project aimed at securing a series of commercial privileges for the grand duchy in the New World during the Iberian Union (1580-1640), the period that saw Spain and Portugal united under the same crown. ${ }^{41}$ Men like Fernandes and Teixeira, who had also been in Brazil, could potentially provide the grand duke with important information about Brazil, its topography, and the current state of its population. Miguel Fernandes in particular could boast a knighthood earned in military exploits in Brazil and the social capital that it entailed in the Iberian world, something that could be useful to the grand duchy if it were to try to make inroads into Brazil. Men like Teixeira and Fernandes could also be instrumental in securing Ferdinando's interest to make inroads into Atlantic commerce, especially as they hailed from the prominent commercial center of Porto. As the son of Dinis Aenes, someone like Miguel Fernandes would also have had the added benefit of belonging to an international mercantile network of over two generations. ${ }^{42}$

Shortly after arriving in Pisa, Fernandes and his father-in-law came to the grand duke's attention. Their troubles began in May 1595 during their journey

39 On the Livornine see Lucia Frattarelli Fischer, "Cristiani nuovi e nuovi ebrei in Toscana fra Cinque e Seicento: Legittimazioni e percorsi individuali," in L'identità dissimulata. Giudaizzanti iberici nell'europa dell'età moderna, ed. Pier Cesare Ioly Zorattini (Florence: Olschki, 200o), 217-31, and Vivere fuori dal Ghetto [...], 15-68.

40 On the ponentini and Venice see the following studies by Benjamin Ravid, "The First Charter of the Jewish Merchants of Venice, 1589," AJs Review 1 (1976): 187-222, and "Venice, Rome and the Reversion of New Christians to Judaism: A Study in Ragione di Stato," in L'identità dissimulata. Giudaizzanti iberici nell'europa dell'età moderna, ed. Pier Cesare Ioly Zorattini (Florence: Olschki, 2000), 151-93.

41 Sergio Buarque de Holanda, "Os projetos de colonização e comércio toscanos no Brasil ao tempo do grão duque Fernando (1587-1609)," Revista de História (2000): 95-122; Carlos Alberto de Moura Ribeiro Zeron and Carlos Ziller Camenietzki, "Nas sendas de Sérgio Buarque de Holanda. Documentos sobre uma expedição florentina a Amazônia em 1608," Revista de História 142-143 (2000): 123-211; Alírio Cardoso, "Um piccolo astaccio al rio dell'amazzoni': Pirataria europeia e projetos italianos na Amazônia na época da monarquia hispânica," Revista de História 170 (2014): 170-99.

42 Nelson Novoa, "The Many Lives," 151-53. 
to Rome in order to secure a home for Fernandes and his wife. They were to be assisted on their way by a prominent Portuguese New Christian, Jerónimo da Fonseca. Expressing his annoyance after not being able to find a house, Fernandes was overheard by a relative of Fonseca's who construed what he heard as a blasphemous remark warranting the attention of the Inquisition. This led to Fernandes's inquisitorial confinement over the spring and summer of 1595 and his release in October 1595, two months after the release of Rui Teixeira, thanks to the diplomatic and financial assistance of the Tuscan grand duke. The great number of Portuguese residents of Pisa who provided testimony in their defense serves to show their standing in the city, where they had only been living for a year. Ironically, their unfortunate brush with the Inquisition coincided with Bento Teixeira's arrest in Pernambuco. During his trial, he mentioned having spoken to one Diogo d'Orta, a New Christian who traveled widely and, at one point, had met up with Rui Teixeira in Pisa, and described him as a practicing Catholic. He mentioned that Rui had heard about Bento's imprisonment. His reaction was not one of surprise but the opposite, that it was to be expected, as he said "ele quis, ele otenha," he got what he was looking for, which would seem to indicate that he had known about his cousin's Judaizing. ${ }^{43}$

After their run-in with the Inquisition in Rome, son- and father-in-law settled into their roles as prominent Portuguese merchants in Pisa. Rui Teixeira's life is relatively well documented. He settled in the parish of San Martino in Kinzica, an important church whose origins date back to the eleventh century, located on the other city of the Arno river from Pisa's most important buildings, but which by then had become a New Christian hub. The Stati delle anime, the parish records of marriages and deaths, the gathering of which became obligatory after the council of Trent $\left(1545^{-1563)}\right.$ provides ample evidence of the Portuguese presence. The parish records show that Teixeira died there on 18 October 1601 ( 1602 according to the Pisan year), and was buried the next day. ${ }^{44}$ The elegant tombstone can still be seen in the church (Fig. 2.3).

43 "E embarcando-me pera Itália vim ter a Pisa, aonde esta o senhor seu primo com irmão Ruy Teixeira, que ia la. Sabia de sua prisão e disse por muitas vezes, 'ele quis, ele otenha,' e justamente estão com ele das portas adentroos dous primos mais de Vossa Mercede Senhor Sebastião Ferreira e Manuel Fernandes, ambos casados com cada huma sua filha de Ruy Teixeira. E perguntando-lhe eu se vivia la catholica e exemplarmente respondeu que sim sed hoc quo ad me implicat et dictione ut pet in mea confessione de Michaele Fernandez, alii vero duo Senhor Ruy Teixeira et Bastião Ferreira fama tantum mihi noti sunt" (fol. 121v). His deposition is dated 14 December 1597.

44 "Addì 18 d'ottobre 1602 al pisano. Morì Messer Rui Tesera portoghese et il seguente giorno fu sepolto in nostra Chiesa di San Martino e pagò per li funerali." San Martino in Kinzica, morti dal 1566 al 1631, Archivio Arcivescovile di Pisa, unnumbered folio. 


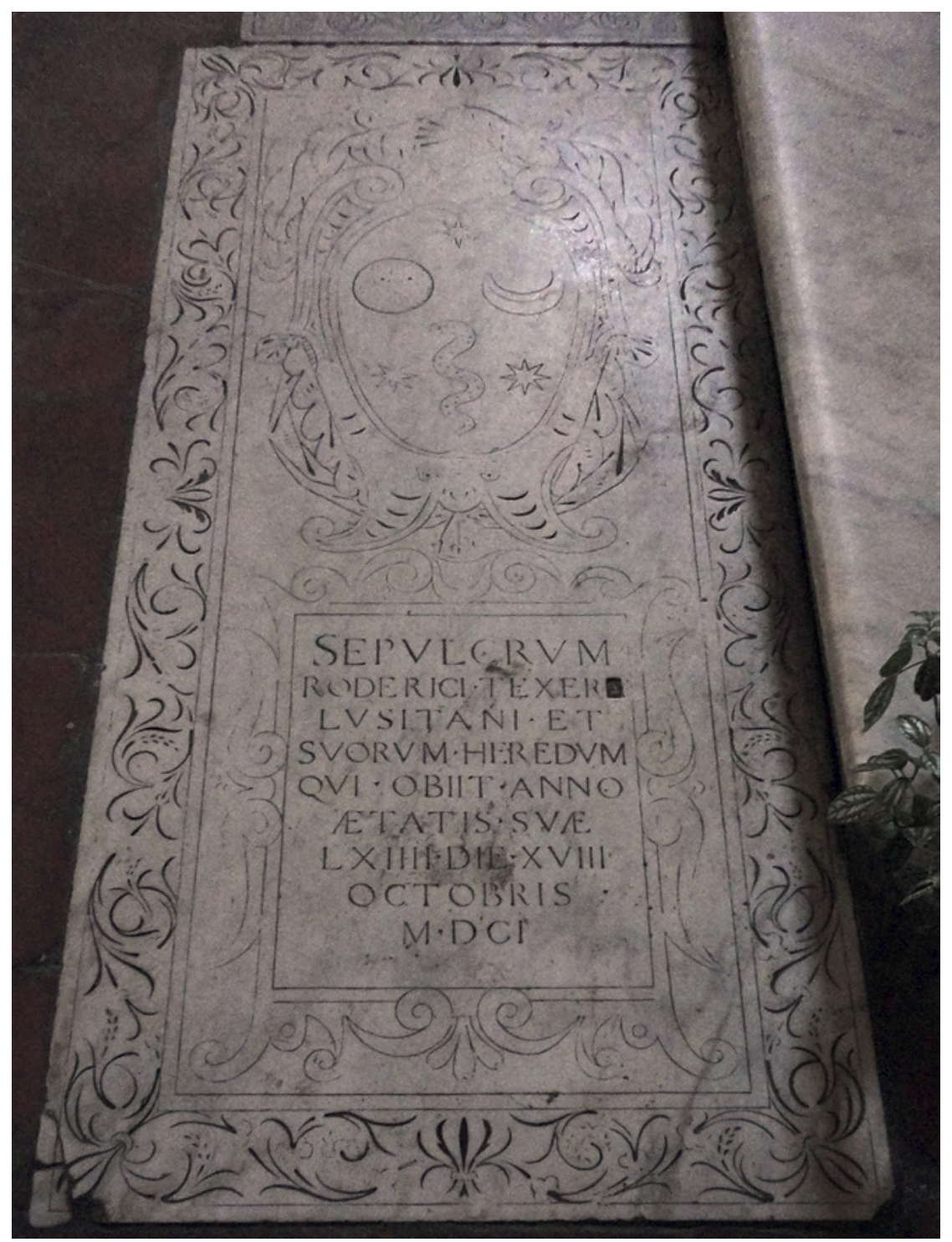

FIgure 2.3 Tombstone of Rui Teixeira, Chiesa di San Martino, Pisa PHOTO: JAMES NELSON NOVOA, ENHANCED COURTESY OF MARTA RAÏCH

\section{$4 \quad$ Lingering Doubts and New Horizons}

Traces of Miguel Fernandes's footsteps seem to end in Pisa. We know that he fathered three children with his wife: Dinis, Branca, and Florença, all names derived from family members. While his orthodoxy would seem to have been 
cleared, the suspicions regarding the family continued to haunt his descendants. Years later, his son Dinis married his cousin Beatriz Dias on 21 December 1622. In 1625, Dias was tried by the tribunal of the Inquisition of Milan, where she had taken up residence. She claimed that they had been married in the home they were to inhabit near the church of San Sepolcro in close vicinity to San Martino. In the room where the wedding took place there was a Bible in Spanish on a table and some kind of blessing was read out loud in Portuguese by her future husband ${ }^{45}$ The trial, transcribed and published by Pier Cesare Ioly Zorattini, provides us with the version of events presented by Beatriz to the Inquisition. As the daughter of Clara Teixeira and grandaughter of Rui Teixeira, she had believed that they had been married with a papal dispensation of consanguinity. She claimed that her husband in reality had no religion, being like the beasts, without a law, only going through the motions at mass and going to confession in order to get along with his mother and sister all the while practicing Jewish fasts at home. ${ }^{46}$

The trial was part of a series of inquisitorial investigations that dogged the female members of the family from 1618 to 1626 from Pisa to Milan to Venice, offering differing versions of events. Dinis's mother Feliciana (by then Miguel Fernandes's widow we assume since there is no mention of Miguel being alive), confessed to having induced her son into Jewish practice. She herself claimed that she was led into error by the Jewish doctor Eliahu Montalto (1567-1616) during his sojourn in Tuscany in 1606-1609. Dinis had apparently been indoctrinated into his Judaizing heresy after a stint in Brazil where he had followed his father's footsteps, presumably in the sugar trade. Feliciana claimed that she reinforced these heretical beliefs in her son upon his return.

The investigations pitted various female members of the Teixeira family against each other. Beatrice, having settled in Milan, denounced her mother and a sister, Clara, as Judaizers while admitting her own apostasy, claiming that they had been lead astray by their mother, Branca de Nis, Rui Teixera's wife. All ended up being condemned to prison for different intervals in order to expiate their crimes of faith.

The truth of inquisitorial trials is a continuous source of academic debate and it cannot be assumed that what was confessed was necessarily factual truth. We can postulate as to the actual intentions and beliefs of the people

45 "Et il matrimonio seguì in casa nostra, che si chiama la casa di San Sepolcro, nella sala sopra un tavolino dov'era una Bibbia aperta in lingua spagnola, e mi marito legè un foglio scritto a mano in lingua portoghese [...]" Processi del S. Uffizio di Venezia contro ebrei e giusaizzanti (1633-1637), ed. Pier Cesare Ioly Zorattini (Florence: Olschki, 1992), 315-16.

46 " $[\mathrm{C}]$ ome le bestie, che non fa a modo né d'una Legge né dell'altra, cioè lui va alla messa et si confessa ma, per non farsi mal volere dalla madre e dalla sorella, in casa fa a modo loro, che li detti digiuni all'hebrea li fa ancora lui [...]." Ibid., 221-22. 
involved and attempt to match these with independent accounts. The case of the Teixeira family nonethless provides, I believe, an interesting sampling of the many faces of the New Christian diaspora across its full geographical range from the Iberian Peninsula to Brazil, and to Italy. In the space of three generations and across these geographical divides spanning the better part of the globe, we see individuals who, at least publicly, adamantly did all they could to attest to their Catholic faith. Others admitted to their Judaizing tendencies, generally invoking their being coaxed into it by family members, especially their mothers.

As Révah's fundamental scholarship has shown, the individuals mentioned here belonged to the same family as Uriel da Costa (1581?-1640), one of the most emblematic and tragic figures of the Sephardic diaspora in one of its most important communities in the early modern period. Reared as a Christian, who received ecclesiastic benefices in the north of Portugal and a humanistic education at the storied university of Coimbra, only to later embrace Judaism, da Costa went on to question the very foundations of rabbinical Judaism during the foundational period of the community of Amsterdam..$^{47}$ One of Miguel Fernandes's siblings, Branca Dinis, married one Bento da Costa Brandão, a New Christian though called "cavaleiro fydallgo da casa da Infante Dona Maria" in notorial documents, were residents of Porto in the rua de São Miguel. It was in that New Christian hub at its parish of Nossa Senhora da Vitória that Gabriel da Costa, who would go on to be called Uriel da Costa, was presumably born sometime in $1581 .^{48}$ As Révah has shown, even though the future author of the Exemplar humanae vitae had been brought up by his father apparently as a practicing Christian, there were also inquisitorial trials that gathered accusations against Bento da Costa Brandão. Révah has speculated as to whether the

47 The literature on Uriel da Costa is considerable. For the sake of brevity we cite only the following: On the community of Amsterdam in these years, see Matt Goldish, "Perspectives on Uriel da Costa's 'Example of a Human Life," Studia Rosenthaliana, 42-43 (2010-2011): 1-23; Israel Salvator Révah, "La religion d'Urel da Costa, Marrane de Porto (D’après des documents inédits)," Revue de l'histoire des religions 161, no. 1 (1962): 45-76; Révah, Uriel da Costa; Uriel da Costa, Examination of Pharisaic Traditions Supplemented by Semuel da Silva's Treatise on the Immorality of the Soul, Translation, notes and introduction H.P. Salomon and I.S.D. Sasson (Leiden and Boston: Brill, 1993); Carl Gebhardt, Die Schriften des Uriel da Costa mit Einleitung, Uebertagung und Regesten (Amsterdam: Menno Hertzberger/Heidelberg: Carl Winters Universitätsbuchhandlung/Oxford University Press, 1922). On the formative years of the Sephardic community of Amsterdam, see the following titles by Yosef Kaplan, Judios nuevos en Amsterdam. Estudios sobre la historia social e intelectual del judaismo sefardí en el siglo XVII (Barcelona: Gedisa, 1996); "From Apostasy to Return to Judaism: The Portuguese Jews in Amsterdam," Binah 1 (1989): 99-117.

Révah, Uriel da Costa, 229-35. 
charges were examples of the constant and random accusations that hovered over all members of the Nação or whether there could have been some truth to his having some degree of attachment to Jewish belief and practice. Doubts nonwithstanding, Costa Brandão died in Porto in 1608 , where he was buried in his parish church of Nossa Senhora da Vitória as a bona fide Catholic. ${ }^{49}$ As with so many members of the Nação, doubt and suspicion were part of the condition of the New Christian in the Peninsula.

Révah has insisted on the importance of Uriel da Costa's formative years in Portugal in understanding his subsequent intellectual and spiritual development. In the Exemplar humanae vitae, he made clear that the skepticism that led him to question the immortality of the soul and the authority and legitimacy of rabbinical Judaism had begun with his doubts regarding Christianity, which had been awakened during his university years in Coimbra. ${ }^{50}$ Uriel da Costa was brought up in a family that belonged to the Nação with firm roots in Porto and was suspected of attachment to Jewish belief for several generations, drawing the attention of inquisitorial authorities in Brazil and Portugal. The consciousness of that belonging, from his childhood in the New Christian hub of São Miguel, to his years in Coimbra, and later on in the midst of the Portuguese Jewish community of Amsterdam, a community which was imposing its own models of confessionalization over its denizens, must have accompanied this fiercely independent and original thinker throughout his lifetime.

The family considered here exemplifies the many possibilities open to New Christians in terms of public expression of their religious allegiances throughout the various locales of the Western diaspora which they encountered. In the Hispanic world, concealment, some degree of attachment to Jewish belief, or total disregard or disavowal of it were the only paths available. Tuscany and Venice, at the end of the sixteenth century offered them the possibility of embracing Judaism and joining the incipient Sephardic communities there. None of the members of the family chose that path, living at least formally as Catholics and suffering inquisitorial justice when they failed to do so completely.

In the cases of Rui Teixeira, Miguel Fernandes, and Bento Teixeira, Portuguese inquisitorial justice was to follow them from Porto to Brazil as a lingering reminder of their membership in the Nação. In the case of the first two, it even followed them to Rome. In spite of their being ostensibly cleansed of their family blemish by having settled in Tuscany and, indeed, by having been summoned there by its ruler, their New Christian origins continued to haunt them as is evinced in their trial. Though it was not in principle directly

49 Ibid., 242-46.

$50 \quad$ Ibid., 531-41. 
on account of their adherence to Jewish belief but rather on account of blasphemy, nevertheless, throughout the proceedings, the suspicions of their continued allegiance to Judaism was constant. It was an occasion for them to present and evoke members of the Nação in Portugal, Brazil, Pisa, and Rome, to the inquisitorial authorities. Their own Roman ordeal occurred shortly before Bento Teixeira was apprehended in Pernambuco, making Rui Teixeira's subsequent affirmation about his cousin's provocation, which resulted in his imprisonment, all the more ironical. Rui's brush with inquisitorial justice in Rome alongside his son-in-law must have made him appreciate the weight of the travail which would be endured by Bento in Pernambuco and later in Lisbon. Branca de Nis and Beatriz Dias, related to the family by kin or marriage, suffered the attention of the Inquisition in Pisa, Milan, and Venice. None chose to openly practice Judaism, even when such a possibility was available to them under the provisions for this in Venice and Tuscany. Uriel da Costa, in turn, renounced his Christian upringing and joined the ranks of the newly minted Jewish community of Amsterdam where he experienced the brunt of communal Jewish religious discipline, which resulted in his exclusion from it and then his tragic suicide.

The cases of these families demonstrate the complexity of the problems of identity that the members of the Western Sephardic diaspora had to contend with, posed by the Christian society they were part of, and by the newly-formed Jewish communities of Sephardic origin. In the myriad cities and towns from the Mediterranean and beyond that saw the creation of New Christian or New Jewish communities, decisions regarding how members chose to live their religious identity were often dictated by the conditions and contexts in which they found themselves. The members of the family that has been considered here were made to contend with the diverse options of public display of religious adherence in different places over several generations. How they did, provides us with an interesting case study of some of the options of belief and practice engaged in by the men and women of the Nação. Alongside the many who constituted the ranks of the great Jewish communities of Livorno, Venice, Amsterdam, and Hamburg, there were also those who were content, determined, or resigned to live in Christian guise.

\section{Bibliography}

Alves, Luiz Roberto. Confissão, poesia e inquisição. São Paulo: Ática, 1983.

Beraldi Ribeiro, Eneida. "Bento Teixeira e a 'Escola de Satanás.' O Poeta que teve a 'prisão por recreação, a solidão por companhia e a tristeza por prazer." $\mathrm{PhD}$ diss., University of São Paulo, 2006. 
Beraldi Ribeiro, Eneida. "Bento Teixeira: Inquisição e sociedade colonial." WebMosaica 4, no. 1 (2012): 50-56.

Boxer, Charles Ralph. "Jorge d'Albuquerque Coelho: A Luso-Brazilian Hero of the Sea, 1539-1602." Luso-Brazilian Review 6, no. 1 (1969): 3-17.

Buarque de Holanda, Sergio. "Os projetos de colonização e comércio toscanos no Brasil ao tempo do grão duque Fernando (1587-1609)." Revista de História (2000): 95-122.

Bujanda, Jesus Maria de., ed. Index de l'Inquisition portugaise 1547, 1551, 1564, 1581. Sherbrooke: Centre d'Études de la Renaissance, 1995.

Capistrano de Abreu, João, ed. Primeira visitação do santo ofício as partes do Brasil pelo licenciado Heitor Furtado de Mendoça, Confissões da Bahia 1591-1592. São Paulo: Homenagem de Paulo Prado, 1922.

Capistrano de Abreu, João, ed. Primeira visitação do santo ofício as partes do Brasil pelo licenciado Heitor Furtado de Mendoça, Confissões da Bahia 1591-1593. São Paulo: Homenagem de Paulo Prado 1925.

Capistrano de Abreu, João, ed. Primeira visitação do santo ofício as partes do Brasil pelo licenciado Heitor Furtado de Mendoça, Confissões da Bahia 1593-1595. São Paulo: Homenagem de Paulo Prado, 1929.

Cardoso, Alírio. "Um piccolo astaccio al rio dell'amazzoni': Pirataria europeia e projetos italianos na Amazônia na época da monarquia hispânica." Revista de História 170 (2014): 170-99.

Chociay, Rogério. "Bento Teixeira e Camões: o verso no verso." Revista de Letras 31 (1991): 17-32.

Costa, Uriel da. Examination of Pharisaic Traditions Supplemented by Semuel da Silva's Treatise on the Immorality of the Soul. Translation, notes and introduction H.P. Salomon and I.S.D. Sasson. Leiden and Boston: Brill, 1993.

Costa, Uriel da. Die Schriften des Uriel da Costa mit Einleitung, Uebertagung und Regesten. Edited by Carl Gebhardt. Amsterdam: Menno Hertzberger/Heidelberg: Carl Winters Universitätsbuchhandlung/Oxford Universitz Press, 1922.

Costigan, Lúcia Helena. "A experiência do converso letrado Bento Teixeira: Um missing link na história intelectual e literária do Brasil-colônia." Revista de Crítica Literaria Latinoamericana 2040 (1994): 77-92.

Costigan, Lúcia Helena. "Empreendimento e resistência do cristão-novo face à política de Filipe II: O processo inquisitorial de Bento Teixeira." Colonial Latin American Review 12 , no. 1 (2003): 37-61.

Costigan, Lúcia Helena. Through Cracks in the Wall. Modern Inquisitions and New Christian Letrados in the Iberian Atlantic World. Leiden and Boston: Brill, 2010.

Cunha de Azevedo Mea, Elvira. “A Inquisição do Porto." Revista de História 2 (1979): $215^{-27}$.

Cunha de Azevedo Mea, Elvira. "Os cristãos-novos, a Inquisição e o Brasil. Séc. XVI." Revista da Faculdade de Letras do Porto 2, no. 4 (1987) 151-77. 
Faria de Assis, Angelo Adriano. "O licenciado Heitor Furtado de Mendonça, inquisidor da primeira visitação do Tribunal do Santo Ofício ao Brasil." In Anais do XXIII Simpósio Nacional de História. Londrina: ANPUH, 2005 cd-rom.

Feitler, Bruno. Inquisition, juifs et nouveaux-chrétiens au Brésil. Le Nordeste XVII et XVIII ${ }^{\text {ème }}$ siècles. Louvain: Presses Universitaires de Louvain, 2003.

Frattarelli Fischer, Lucia. "Cristiani nuovi e nuovi ebrei in Toscana fra Cinque e Seicento: Legittimazioni e percorsi individuali." In L'identità dissimulata. Giudaizzanti iberici nell'europa dell'età moderna. Edited by Pier Cesare Ioly Zorattini, 217-31. Florence: Olschki, 2000.

Frattarelli Fischer, Lucia. "Ebrei a Pisa fra Cinquecento e Settecento." In Gli ebrei di Pisa (secoli IX-XX). Atti del Convegno internazionale. Pisa, 3-4 ottobre 1994. Pp. 89-115. Pisa: Pacini editore, 1998.

Frattarelli Fischer, Lucia. Vivere fuori dal Ghetto. Ebrei a Pisa e Livorno (secoli XVIXVIII). Turin: Silvio Zamorani Editore, 2008.

Freyre, Gilberto. “Acerca da Prosopopéia." Revista de Pernambuco 1, no. 1 (1927): 2-61.

Goldish, Matt. "Perspectives on Uriel da Costa's 'Example of a Human Life." Studia Rosenthaliana 42-43 (2010-2011): 1-23.

Gonsalves de Mello, José Antônio. "Bento Teixeira, autor da Prosopopéia." In Estudos Pernambucanos. Crítica e problemas de algumas fontes de história de Pernambuco. Pp. 13-52. Recife: Fundarpe, Direitoria de Assuntos Culturais, 1986.

Gonsalves de Mello, José Antônio. "Um tribunal da inquisição em Olinda, Pernambuco (1594-1595)." Revista da Universidade de Coimbra 36 (1991): 369-74.

Gonsalves de Mello, José Antônio. Gente da nação. Recife: Editora Massangana, 1996.

Goncalves Salvador, José. Os cristãos novos. Povoamento e conquista do solo brasileiro (1530-1680). São Paulo: Livraria Pioneira Editora, Editora da Universidade de São Paulo, 1976.

Goncalves Salvador, José. Os cristãos novos e o comércio no Atlântico meridional. São Paulo: Livraria Pioneira Editora, Editora da Universidade de São Paulo, 1978.

Graizbord, David. "Religion and Ethnicity among "Men of the Nation: Towards a Realistic Interpretation." Jewish Social Studies: History, Culture, Society 15, no. 1 (2008): $3^{2-65}$.

Ioly Zorattini, Pier Cesare, ed. Processi del S. Uffizio di Venezia contro ebrei e giusaizzanti (1633-1637). Florence: Olschki, 1992.

Israel, Jonathan I. Diasporas within a Diaspora:Jews, Crypto-Jews and the World Maritime Empires, 1540-1740. Leiden: Brill, 2002.

Kagan, Richard L., and Morgan, eds. Atlantic Diasporas. Jews, Conversos and CryptoJews in the Age of Mercantilism 1500-180o. Baltimore: The Johns Hopkins University Press, 2009.

Kaplan, Yosef. "From Apostasy to Return to Judaism: The Portuguese Jews in Amsterdam." Binah 1 (1989): 99-117. 
Kaplan, Yosef. Judíos nuevos en Amsterdam. Estudios sobre la historia sociale intelectual del judaísmo sefardí en el siglo XVII. Barcelona: Gedisa, 1996.

Marcocci, Giuseppe and Paiva, José Pedro. "Inquisizione di Porto." In Dizionario storico dell'Inquisizione. Vol. 3: 1240-41. Pisa: Edizioni dela Normale, 2010.

Morais Barros, Amândio Jorge. "Barcos e gentes do mar do Porto (séculos XIV-XVI)." Revista da Faculdade de Letras 14 (1997): 167-230.

Mota Menezes, José Luiz. A recriação do paraíso. Judeus e cristão-novoa em Olinda e no Recife nos séculos XVI e XVII. Recife: Companhia Editora de Pernambuco, 2016.

Mott, Luiz. Primeira visitação do santo ofíicio a Bahia (1591). 1-26. EDUFBA, 2010. http:// books.scielo.org/id/yn/pdf/mott-9788523208905-03.

Moura Ribeiro Zeron, Carlos Alberto de and Ziller Camenietzki, Carlos. "Nas sendas de Sérgio Buarque de Holanda. Documentos sobre uma expedição florentina a Amazônia em 1608." Revista de História 142-143 (2000): 123-211.

Nelson Novoa, James. "Negotiating Identity Among the Nação in Early Modern Rome." In Early Modern Ethnic and Religious Communities in Exile. Edited by Yosef Kaplan, 242-76. Newcastle upon Tyne: Cambridge Scholars Publishing, 2017.

Nelson Novoa, James. "The Many Lives of Two Portuguese Conversos: Miguel Fernandes and Rui Teixeira in the Tribunal of the Holy Office in Rome." Hispania Judaica 12 (2016): 127-84.

Piloto, Afonso Luiz. Naufragio, que passou Jorge D'Albuquerque Coelho, capitão e governador de Pernambuco Lisbon: por António Alvarez, vendemse em casa de António Ribeyro livreyro em a Rua Nova, 1601.

Processo da Inquisição de Lisboa, 5206, Arquivo Nacional da Torre do Tombo, Lisbon.

Pulido Serrano, Juan Ignacio. “Plural identities: The Portuguese New Christians," Jewish History 25 (2011): 129-51.

Ravid, Benjamin. "The First Charter of the Jewish Merchants of Venice, 1589." AJs Review 1 (1976): 187-222.

Ravid, Benjamin. "Venice, Rome and the Reversion of New Christians to Judaism: A Study in Ragione di Stato." In L'identità dissimulata. Giudaizzanti iberici nell'europa dell'età moderna. Edited by Pier Cesare Ioly Zorattini, 151-93. Florence: Olschki, 2000.

Révah, Israël Salvator. "La religion d'Urel da Costa, Marrane de Porto (D’après des documents inédits)." Revue de l'histoire des religions 161, no. 1 (1962): 45-76.

Révah, Israël Salvator. Uriel da Costa et les marranes de Porto. Cours au Collège de France 1966-1972. Edited by Carsten L. Wilke. Paris: Fundação Calouste Gulbenkian, 2004.

Rinaldi, Lucinéa. Entre a Prosopopeia e a viagem: Poética e narrativa por letras coloniais. PhD diss., University of São Paulo, 2016.

Ruspio, Francesca. La nazione portoghese. Ebrei ponentini e nuovi cristiani a Venezia. Turin: Silvio Zamorani editore, 2007.

Ruspio, Francesca. "Una comunità di marrani a Venezia." Zakhor 5 (2001): 53-85. 
San Martino in Kinzica, morti dal 1566 al 1631. Archivio Arcivescovile di Pisa, Pisa.

Souza e Silva, Emanuel Luiz. "Juntos à Forca': A Família Lopes e a Visitação do Santo Oficio à Bahia (1591-1593)." Master's thesis, Universidade Estadual de Feira de Santana, 2010.

Studnicki-Gizbert, Daviken. A Nation upon the Ocean Sea. Portugal's Atlantic Diaspora and the Crisis of the Spanish Empire, 1492-1640. New York: Oxford University Press, 2007.

Teixeira, Bento. Naufrágio que passou Jorge de Albuquerque Coelho vindo do Brasil para este reino do ano de 1565. Edited by Augusto César Pires de Lima. Porto: Livraria Simões Lopes de Domingos Barreira, 1938.

Teixeira, Bento. Prosopopea. Edited by Afrânio Peixoto. Rio de Janeiro: Academia Brasileira, 1923.

Teixeira, Bento. Prosopopea. Edited by Benjamin Franklin Ramiz Galvão. Rio de Janeiro: Tipografia do Imperial Instituto Artístico, 1873.

Trivellato, Francesca. The Familiarity of Strangers: The Sephardic Diaspora, Livorno, and Cross-Cultural Trade in the Early Modern Period. New Haven: Yale University Press, 2009.

Vainfas, Ronaldo, ed. Santo Oficio da Inquisição de Lisboa. Confissões da Bahia, São Paulo: Companhia das Letras, 1997.

Vilar de Carvalho, Gilberto. O primeiro brasileiro. São Paulo: Marco Zero, 1995. 